\title{
Kardiomiopatia z niescalenia mięśnia lewej komory
}

\author{
Non-compaction cardiomyopathy
}

\author{
Natalia Pietraszek ${ }^{1}$, Dorota Piotrowska-Kownacka ${ }^{2}$, Renata Główczyńska ${ }^{1}$ \\ ${ }^{1}$ I Katedra i Klinika Kardiologii, Warszawski Uniwersytet Medyczny \\ ${ }^{2}$ I Zakład Radiologii Klinicznej, Warszawski Uniwersytet Medyczny
}

\section{Streszczenie}

Kardiomiopatia z niescalenia jest niezwykle rzadko spotykaną odmianą kardiomiopatii uwarunkowanej genetycznie i występującej zarówno rodzinnie, jak i sporadycznie. Polega ona na nadmiernym beleczkowaniu oraz na występowaniu głębokich zachyłków pomiędzy tymi beleczkami. Najczęściej wykrywana jest zupełnie przypadkowo w trakcie echokardiografii lub podczas screeningu członków rodziny. Choć nie ma złotych standardów diagnostyki kardiomiopatii z niescalenia, to najszerzej na świecie stosowane są kryteria Jenni i wsp. podczas badania echokardiograficznego. Leczenie tej kardiomiopatii opiera się głównie na spowalnianiu progresji niewydolności serca, na profilaktyce przeciwzakrzepowej oraz na leczeniu zaburzeń rytmu serca. U niektórych grup pacjentów wskazane jest również wszczepienie kardiowertera-defibrylatora, a nawet należy rozważyć przeszczepienie serca.

Słowa kluczowe: kardiomiopatia z niescalenia, niewydolność serca, echokardiografia, rezonans magnetyczny

Folia Cardiologica 2018; 13, 4: 378-385

\section{Wstęp}

Kardiomiopatia z niescalenia mięśnia lewej komory (LVNC, left-ventricular non-compaction cardiomyopathy) jest to rzadko spotykana kardiomiopatia polegająca na nadmiernym beleczkowaniu mięśnia oraz na obecności głębokich zachyłków pomiędzy tymi beleczkami. LVNC została zaklasyfikowana jako kardiomiopatia pierwotna o podłożu genetycznym - jest dziedziczona autosomalnie dominująco, a do jej powstawania przyczyniają się mutacje w kilku genach [1, 2]. Takie nieadekwatne beleczkowanie najczęściej można zaobserwować na koniuszku serca. Może ona być izolowana lub towarzyszyć zaburzeniom układu mięśniowo-kostnego [3]. Według Towbin i wsp. kardiomiopatia ta może być utożsamiana z hipertrofią mięśnia sercowego, dysfunkcją skurczową lub rozkurczową (czasami nawet obydwiema), a także różnymi odmianami wad wrodzonych [4]. Częstość występowania ocenia się na 0,05\% w populacji ogólnej [5].

\section{Patogeneza}

W trakcie rozwoju płodowego, serce powstaje z zapętlonej cewy sercowej [6]. Budową przypomina wtedy siatkę złożoną z włókien mięśniowych oraz beleczek przedzielonych zachyłkami [7]. Przed powstaniem krążenia wieńcowego, zachyłki te komunikują się z jamą komory. Natomiast, po powstaniu krążenia wieńcowego, miokardium komór zaczyna ulegać procesowi kompakcji, a zachyłki przekształcają się w kapilary. Następnie, pomiędzy 6. a 8. tygodniem życia płodowego, beleczki powinny zacząć się scalać, począwszy od podstawy serca, a kończąc na koniuszku $[3,7]$. Jednakże u osób cierpiących na kardiomiopatię z niescalenia do takiego procesu nie dochodzi - dlatego też serca z LVNC pozostają z nadmiernym beleczkowaniem oraz głębokimi zachyłkami. Taki brak scalenia jest niezależny od tego, czy rozwój naczyń wieńcowych przebiegał prawidłowo, czy też nie [6]. Rooms i wsp. zaznaczają również, iż nie wiadomo, czy mechanizmem braku scalenia jest nieprawidłowość

Adres do korespondencji: dr n. med Renata Główczyńska, Katedra i Klinika Kardiologii, Warszawski Uniwersytet Medyczny, ul. Banacha 1a, 02-097 Warszawa, e-mail: reng@op.pl 
morfogenezy prawidłowego miokardium, czy też zahamowanie rozwijającego się miokardium [3].

Chociaż kardiomiopatia z niescalenia jest klasyfikowana jako kardiomiopatia uwarunkowana genetycznie, to do tej pory nie znaleziono konkretnego genu, który by za nią odpowiadał. Może występować sporadycznie, jak i rodzinnie. Co więcej, jest ona dziedziczona różnorako - zarówno autosomalnie dominująco, autosomalnie recesywnie jak i mitochondrialnie, a także jest może być sprzężona recesywnie z chromosomem X [4, 8]. Najczęstszą postacią jest ta dziedziczona autosomalnie dominująco [8].

Sprzężenie z chromosomem X (lokalizacja - Xq28) występuje w zespole Bartha i kojarzone jest z mutacjami w genach TAZ lub G4.5 kodującymi acetylotransferaze $[4,8,9]$. Występuje ono wyłącznie u mężczyzn, aczkolwiek Towbin i wsp. donoszą, iż została opisana jedna kobieta z taką kardiomiopatią [4].

Dziedziczenie dominujące warunkuje współwystępowanie wad wrodzonych serca, a także wrodzone defekty budowy serca. Jest to grupa niejednorodna, ponieważ nie zawsze jest ona wykrywana rodzinnie od razu - czasami mutacje powodują mniejsze defekty niekoniecznie dające objawy kliniczne - na przykład przetrwały przewód tętniczy lub mały ubytek w przegrodzie międzyprzedsionkowej.[4] Ostatnie badania pokazują, iż w tym rodzaju dziedziczenia odpowiedzialna za powstawanie LVNC może być mutacja w regulatorze szlaku NOTCH - MIB1 [8].

Poza tym stwierdzono, iż mutacja w genie $\alpha$-dystrobrewiny (białka cytoszkieletu) jest identyfikowana u pacjentów z wrodzoną wadą serca, natomiast mutacja białka Cypher/ZASP w prążku Z (białko znajdujące się w cytoplazmie mięśni serca i szkieletu) jest utożsamiana z kardiomiopatią rozstrzeniową [8]. W wyniku tych mutacji LVNC występuje równoczasowo z dysfunkcją lewej komory [9].

Co więcej, odkryto, iż mutacje do tej pory kojarzone z innymi rodzajami kardiomiopatii mogą przyczyniać się do powstania kardiomiopatii z niescalenia. Na przykład, mutacja białka A/C lamininy obecna w kardiomiopatii rozstrzeniowej oraz mutacja białek sarkomerów obecna w kardiomiopatii przerostowej [8].

Należy również zaznaczyć dwie kwestie. Po pierwsze, $\mathrm{u}$ wielu rodzin występowanie kardiomiopatii z niescalenia było uwarunkowane więcej niż jedną mutacją [4]. A po drugie, u wielu pacjentów nie można z powodzeniem uzyskać ich genotypu i określić rodzaju mutacji u nich występującej $[8,10,11]$.

\section{Obraz kliniczny}

Niescalenie mięśnia lewej komory bardzo długo może przebiegać bezobjawowo. Nie ma konkretnego przedziału wiekowego, kiedy kardiomiopatia ta się ujawnia. Niekiedy pozostaje ona zdiagnozowana dopiero w końcowym stadium niewydolności serca [4]. Bardzo często jest ona wykrywana w trakcie screeningu członków rodziny osoby dotkniętej LVNC, albo w trakcie przypadkowej echokardiografii.

Niemniej jednak, typową triadą objawów towarzyszącą LVNC są: rozwój niewydolności serca, wystąpienie zatoru systemowego oraz powstanie zaburzeń rytmu (szczególnie częstoskurczu komorowego) [2, 12]. Tak więc, LVNC jest najczęściej wykrywane w trakcie diagnostyki niewyjaśnionej niewydolności serca $[7,13]$. Poza tym, kardiomiopatii z niescalenia może towarzyszyć nagły zgon sercowy, a także mało specyficzne objawy, typu: ból w klatce piersiowej, omdlenia, duszność, kołatanie serca.

\section{EKG}

Nie istnieją żadne cechy szczególne w EKG pomagające nam zdiagnozować kardiomiopatię z niescalenia. Co więcej, 10-25\% pacjentów z LVNC może nie mieć żadnych nieprawidłowości w zapisie tego badania, a jeśli już wystąpią, to są one niespecyficzne $[8,14]$. Niemniej jednak, najczęstszymi zaburzeniami, które możemy znaleźć w badaniu są zaburzenia repolaryzacji (zaburzenia fali $\mathrm{ST} / \mathrm{T}$ ), cechy przerostu lewej komory (ryc. 1), migotanie przedsionków, a także blok lewej odnogi pęczka Hisa $[4,8,14]$. Poza tym, Finsterer i wsp. wymieniają również szereg możliwych nieprawidłowości widocznych w Holterze-EKG, np. bigeminie komorowe, bradykardię zatokową i nieutrwaloną tachykardię komorową [14]. Co ciekawe, u 15\% pacjentów pediatrycznych zostało opisane występowanie zespołu Wolffa-Parkinsona-White'a. Nie występował on jednak u pacjentów dorosłych [8].

\section{Obraz echokardiograficzny}

Jak już zostało wspomniane, LVNC jest najczęściej wykrywane w trakcie przypadkowej echokardiografii. Nie ma jednak złotego standardu, aby zdiagnozować LVNC. Często obserwowane jest powiększenie jamy lewej komory (ryc. 2A) oraz obniżona frakcja wyrzutowa lewej komory (ryc. 2B). Niemniej, wśród najważniejszych cech w obrazie ECHO możemy wyróżnić: 1) grube, dwuwarstwowe miokardium złożone z warstwy scalonej (nasierdzie) oraz niescalonej (wsierdzie) (ryc. 3A), a także głębokie zachyłki endomiokardialne (ryc. 3B); 2) maksymalny końcowoskurczowy wskaźnik NC/C >2; 3) zachyłki między beleczkami są głęboko perfundowane, co jest widoczne w kolorowym Dopplerze; 4) niescalenie umiejscowione jest głównie na koniuszku (ryc. 3) oraz w obszarze środkowym komory, zarówno w ścianie dolnej oraz bocznej mięśnia sercowego. Są to kryteria zaproponowane przez Jenni i wsp. i są one najszerzej używane na świecie [15]. Co więcej, Arbustini i wsp. podają tylko wskaźnik niescalenia/scalenia (NC/C) jako najważniejsze kryterium diagnostyczne [16]. Dla LVNC wskaźnik ten musi być większy niż 2,0 w fazie końcowoskurczowej przy uwidocznieniu serca w projekcji przymostkowej, 
w osi krótkiej. Ponadto nie mogą współistnieć inne nieprawidłowości serca [7].

Z kolei, Chin i wsp. sugerują nieco odmienne kryterium - zmierzyli oni odległość od powierzchni nasierdzia do zachyłku $(X)$ oraz odległość od powierzchni nasierdzia do końca beleczki (Y) [17]. Stosunek X/Y dla LVNC ma wartość mniejszą bądź równą 0,5. Tutaj też serce powinno zostać uwidocznione w projekcji przymostkowej, w osi krótkiej [7].

Ponadto, przy użyciu kolorowego Dopplera powinny zostać uwidocznione głębokie zachyłki wypełniające się krwią.

Dodatkowo, do nieprawidłowości morfologicznych, często dochodzą dysfunkcje skurczowe i rozkurczowe. Arbustini i wsp. donoszą, iż nawet dzieci doświadczają zaburzeń rozkurczowych. Są one związane z nieadekwatną relaksacją mięśnia sercowego ze względu na nadmierne beleczkowanie [16].
Nie można jednak zapominać o pacjentach, u których uzyskanie obrazu w badaniu echokardiograficznym jest utrudnione - na przykład u pacjentów z chorobami serca. Dlatego można również wykorzystać kontrast w badaniu ECHO. Wspomaga to uwidocznienie granic śródsierdzia [16].

Co więcej, Mavrogeni i wsp. zaznaczają, iż echokardiografia nie spełnia swojego zadania, jeśli chodzi o różnicowanie kardiomiopatii z niescalenia z kardiomiopatią przerostową, rozpoznawaniu skrzepliny w komorze serca, a także arytmogennej kardiomiopatii prawej komory [2].

Na rycinie 1 przedstawiono powiększoną jamę lewej komory z frakcją wyrzucania oszacowaną na poziomie $40 \%$. Na rycinie 2 widoczne wyraźne beleczkowanie koniuszka lewej komory.
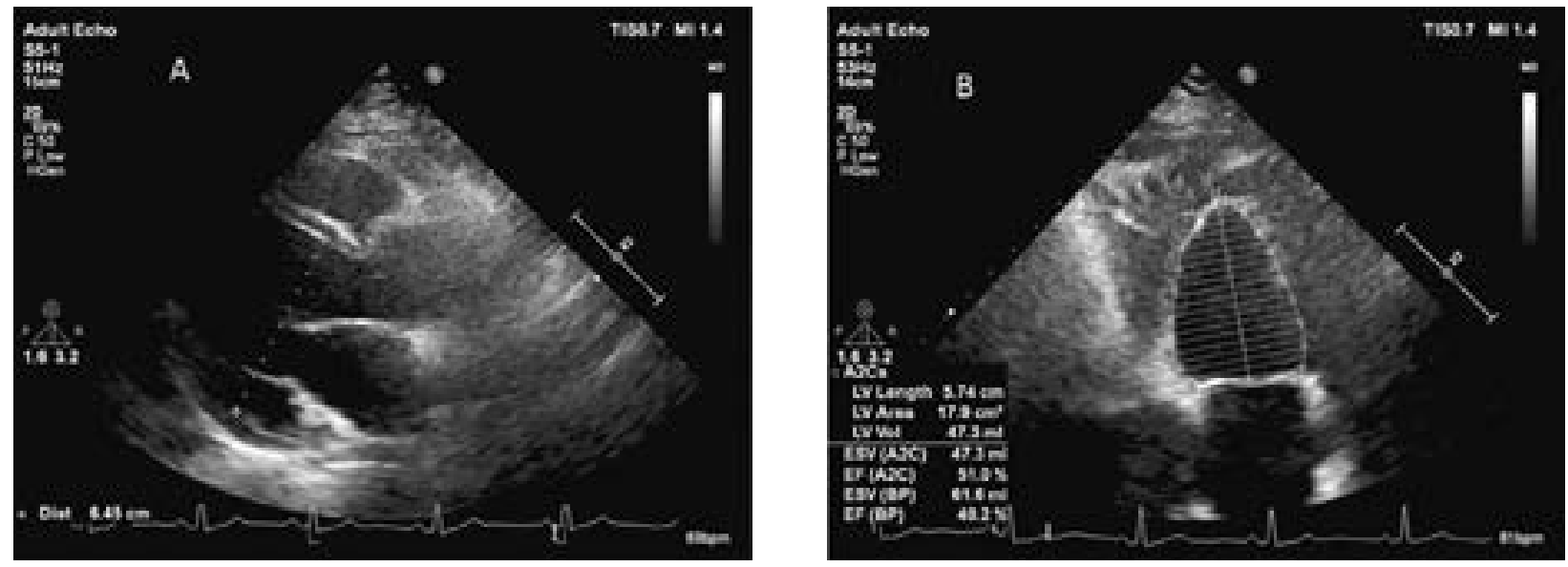

Rycina 1. Zapis EKG u 28-letniej kobiety z niewydolnością serca NYHA III kwalifikowanej do przeszczepienia serca. Cechy przerostu lewej komory i nieprawidłowości lewego przedsionka
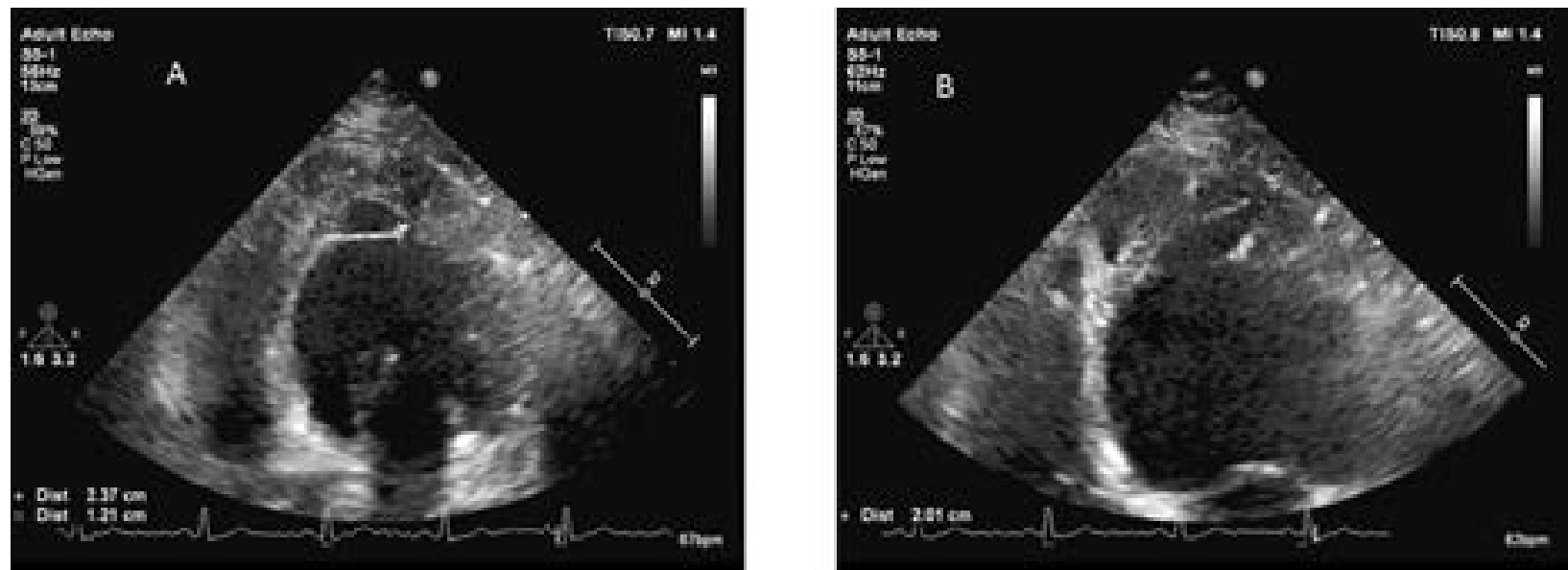

Rycina 2. Badanie echokardiograficzne u 40-letniego mężczyzny z niewydolnością serca w klasie NYHA II. A. Projekcja przymostkowa w osi długiej. Widoczne powiększone lewa komora i lewy przedsionek. B. Frakcja wyrzutowa wyliczona metodą Simpsona (EF 40\%) 
A
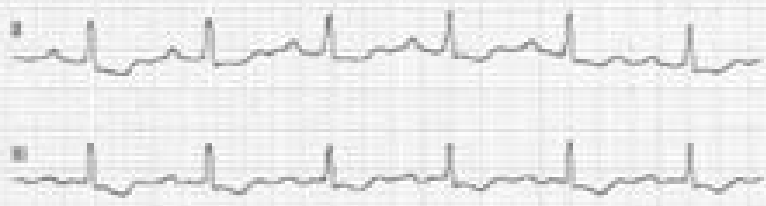

$\operatorname{san}$

a

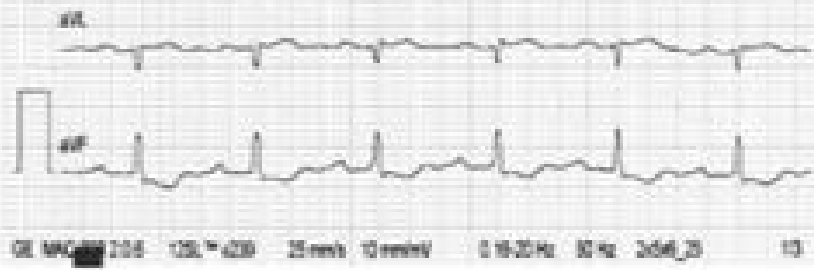

B

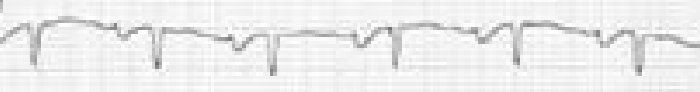

a

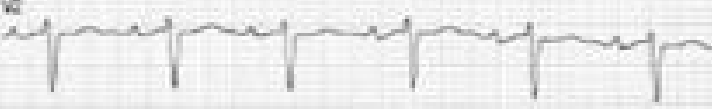

$\therefore$

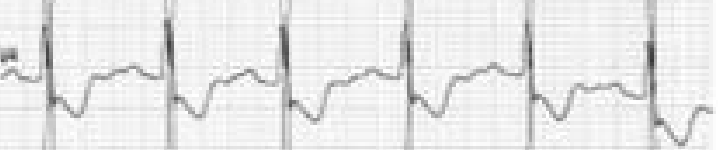

is.

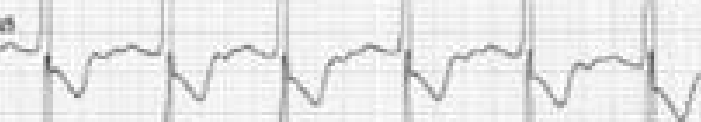

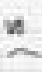
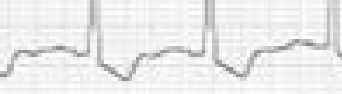

$3 \mathrm{man}$ thrm

diste sete tate

Rycina 3. Badanie echokardiograficzne u 40-letniego mężczyzny z niewydolnością serca w klasie NYHA II. Projekcja koniuszkowa 4-jamowa z zoom na na koniuszek lewej komory. Wyraźne beleczkowanie koniuszka z widocznymi lakunami (A i B).

\section{Obraz w rezonansie magnetycznym}

Kryteria diagnostyczne w tomografii rezonansu magnetycznego są równie kontrowersyjne, jak te używane w echokardiografii. Niemniej, badania MR używa się coraz częściej w trakcie diagnostyki LVNC - potwierdza on występowanie niescalenia. Kryteria diagnostyczne tutaj również są oparte na wskaźniku porównującym ze sobą grubość warstwy niescalonej do scalonej, aczkolwiek wartości wahają się pomiędzy 2-3:1, pomiar uzyskiwany jest w fazie końcoworozkurczowej, a nie końcowoskurczowej na obrazach w przekroju w osi długiej serca [4].

Co ciekawe, Towbin i wsp. zwracają uwagę na to, iż ponieważ warstwa scalona jest często nieadekwatnie cienka, bardzo łatwo można ją pomylić z tętniakiem koniuszka [4].

Pierwsze kryterium diagnostyczne LVNC metodą rezonansu magnetycznego zaproponowali Petersen i wsp. W swoim badaniu porównali 7 pacjentów z LVNC z pacjentami zdrowymi, sportowcami, a także z pacjentami z kardiomiopatią rozstrzeniową, przerostową oraz z nadciśnieniem tętniczym i stenozą aortalną. Zauważyli oni, iż końcoworozkurczowy wskaźnik NC/C jest cennym parametrem rozróżniającym patologiczne niescalenie od niescalenia o mniejszym stopniu w zdrowych sercach, lub w sercach z kardiomiopatią rozstrzeniową lub przerostową. W takim przypadku wskaźnik ten powinien być wyższy niż 2,3 . Jest to pierwsze kryterium diagnozujące LVNC w trakcie badania rezonansem magnetycznym (ryc. 4 i 5). Drugim jest obecność dwuwarstwowego wsierdzia. Wskaźnik NC/C powyżej 2,3 jest obecnie najczęściej rutynowo stosowanym kryterium diagnostycznym $\operatorname{LVNC}[5,12,19]$.
Na podstawie badań i praktyki klinicznej wykazano, że jest to kryterium czułe ale wykrywa również postaci LVNC nieistotne klinicznie.

Jacquier i wsp. przeprowadzili badania na 16 pacjentach z LVNC oraz na pacjentach z kardiomiopatią przerostową, rozstrzeniową i na grupie kontrolnej. Próbowali oni uzyskać optymalną metodę na pomiar masy beleczkowania lewej komory przy użyciu rezonansu magnetycznego serca oraz określić rolę tej masy w diagnostyce LVNC. Ich odtwarzalna metoda ukazała, iż masa beleczkowania lewej komory stanowiąca powyżej 20\% masy całej komory stanowi specyficzny i czuły wskaźnik diagnostyczny dla kardiomiopatii z niescalenia $[1,19]$. Wadą tej metody jest niewątpliwie długi czas analizy i konieczność zastosowania dedykowanego oprogramowania.

Beleczkowanie w lewej komorze stanowi swoiste kontinuum. Największym wyzwaniem jest rozgraniczenie pomiędzy nasilonym beleczkowaniem mieszącym się jeszcze w normie rozwojowej a kardiomiopatią. Grothoff i wsp. zaproponowali następujące cztery kryteria rozpoznawania LVNC na podstawie obrazu rezonansu magnetycznego: 1) masa niescalonego mięśnia lewej komory > 25\%; 2) całkowity wskaźnik masy niescalonego mięśnia lewej komory $>15 \mathrm{~g} / \mathrm{m}^{2}$; 3) Wskaźnik NC/C $\geq 3: 1$ w przynajmniej jednym segmencie, poza segmentem koniuszkowym; 4) beleczkowanie w segmentach $4-6 \geq 2: 1$ (NC/C) [18]. Powyższe kryteria można stosować osobno lub łącznie, przy czym najwyższą czułość i specyficzność Grothoff i wsp. uzyskali dla co najmniej dwóch z 4 kryteriów odpowiednio 100\% i 95\%, a w przypadku stosowania pojedynczego kryterium odpowiednio 100\% i 93\% dla 


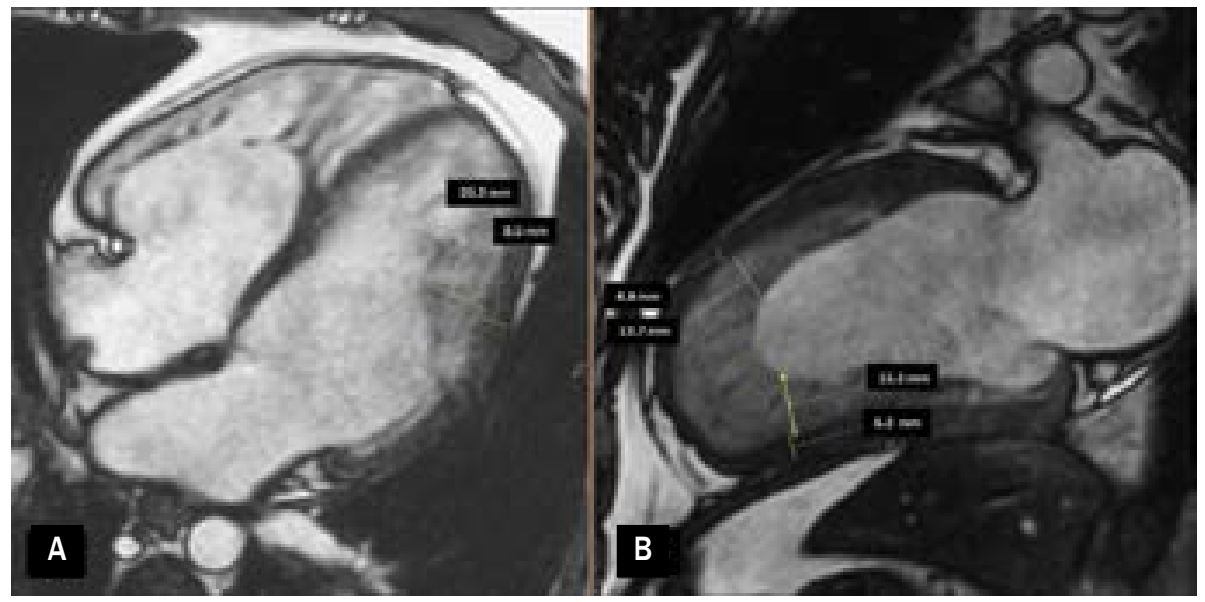

Rycina 4 Obrazy rezonansu magnetycznego u 19 letniego chorego bez objawów niewydolności serca. Rozległe obszary niescalonego mięśnia we wszystkich segmentach koniuszkowych (wskaźnik $\mathrm{NC} / \mathrm{N} \geq 3$ ) oraz środkowych lewej komory wskaźnik > 2.3 mierzone w przekrojach w osi długiej; A. przez lewą komorę i lewy przedsionek, B. w przekroju czterojamowym

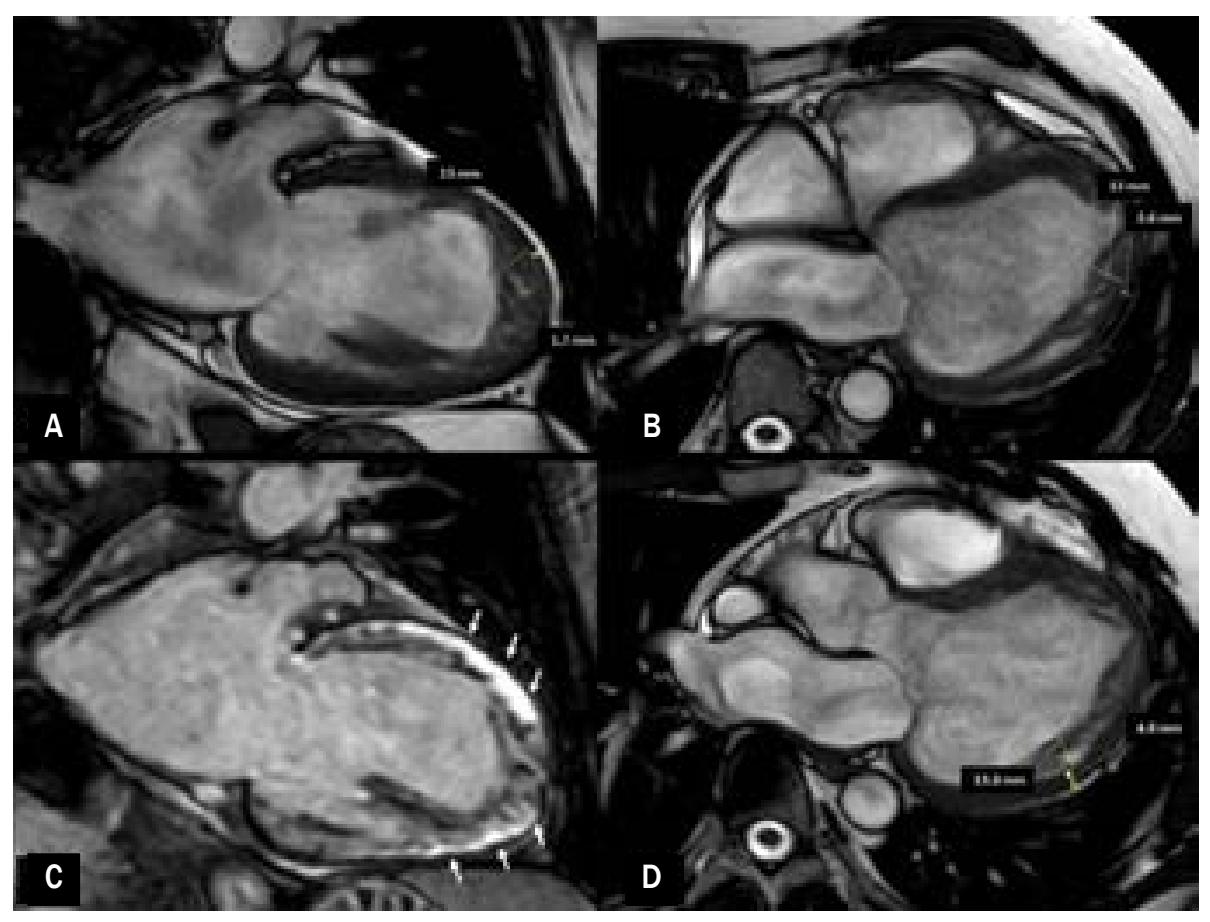

Rycina 5. Obrazy rezonansu magnetycznego 45 letniego chorego z objawami niewydolności lewo-komorowej serca, obniżoną EF do 30\% i rozległymi obszarami późnego wzmocnienia kontrastowego (C, strzałki). Wskaźnik niescalonego/scalonego mięśnia $\geq 3$ w segmentach koniuszkowych oraz bocznych środkowych mierzony w przekrojach w osi długiej serca A. przekrój w osi długiej przez lewą komorę i lewy przedsionek, B. przekrój czterojamowy, D. przekrój pięciojamowy

wskaźnika NC/C $\geq 3: 1$ w przynajmniej jednym segmencie 1-16. Należy przy tym zaznaczyć, że kryteria 1 i 2 wymagają ręcznej segmentacji niescalonego mięśnia na obrazach uzyskanych w osi krótkiej, co jest procedurą czasochłonną, a dodatkowo z uwagi na wymagania softwarowe nie zawsze jest technicznie możliwą do wykonania.
Kontrowersje dotyczą nie tylko kryteriów diagnostycznych LVNC. Grohoff i wsp uważają, że w izolowanej postaci LVNC nie obserwuje się obszarów późnego wzmocnienia kontrastowego (ryc. 5c). Natomiast zarówno Hussein i wsp. oraz Towbin i wsp. zwracają uwage na to, iż późne wzmocnienie kontrastowe pomimo tego, iż jest markerem 
włóknienia mięśnia sercowego, to tutaj jest ono utożsamiane z cechami klinicznymi niescalenia, włączając $w$ to objawy, zmiany w EKG oraz zmniejszoną frakcję wyrzutową $[4,13]$. Tak samo, badanie przeprowadzone przez Mavrogeni i wsp. pokazuje, iż późne wzmocnienie kontrastowe jest niezależnym czynnikiem predykcyjnym wystąpienia częstoskurczu komorowego [2].

Należy również wspomnieć, iż Mavrogeni i wsp. wskazują na to, iż używanie rezonansu magnetycznego pozwala oszacować także ryzyko progresji niewydolności serca [2].

\section{Leczenie}

Do tej pory, nie opracowano specyficznej terapii dla pacjentów z izolowaną kardiomiopatią z niescalenia, aczkolwiek bardzo istotne jest leczenie objawowe $u$ takich osób, to znaczy niewydolności serca oraz zapobieganiu jej progresji, leczenie arytmii, profilaktyka przeciwzakrzepowa. Należy również zapobiegać powikłaniom, takim jak udar, zatorowość, arytmie komorowe oraz niewydolności serca [14].

\section{Kogo leczyć i jak?}

Według Thavendiranathan i wsp., bezobjawowi pacjenci powinni podlegać badaniom co 2-3 lata, ponieważ ich prognoza przeważnie jest dobra. Zaleca się, aby przy każdej takiej wizycie pacjenci z kardiomiopatią z niescalenia mieli wykonywane badanie echokardiograficzne, a także powinni oni mieć założony Holter EKG, aby wykluczyć potencjalnie występujące nieme klinicznie arytmie [20].

Thavendiranathan i wsp. zakładają również, iż pacjenci bezobjawowi, ale z uwidocznioną w ECHO dysfunkcją skurczową lub rozkurczową powinni zostać poddani leczeniu objawowemu niewydolności serca, a także powinni mieć przeprowadzane wizyty kontrolne nie rzadziej niż co 2 lata [20].

Natomiast objawowi pacjenci powinni być leczeni zgodnie z objawami jakie prezentują oraz zgodnie z ich nasileniem. Captur i wsp. zaznaczają, iż każdy pacjent prezentujący jakikolwiek objaw związany z LVNC powinien być poddany leczeniu [10]. Thavendiranathan i wsp. zalecają również, aby wykonać badanie angiograficzne, aby wykluczyć zwężenia w tętnicach wieńcowych. Ważne jest tutaj również badanie neurologiczne [20].

\section{Profilaktyka przeciwzakrzepowa}

Zdarzenia zakrzepowo-zatorowe są obecnie dużym problemem u pacjentów z kardiomiopatią z niescalenia. Ikeda i wsp. zaznaczają, iż częstość ich występowania waha się od $5 \%$ do $38 \%$, a ryzyko ich powstania zwiększa się u pacjentów z migotaniem przedsionków oraz dysfunkcją skurczową lewej komory. Co więcej, głębokie zachyłki oraz obfite beleczkowanie przyczyniają się do zastoju krwi i formowania się zakrzepów. Niemniej jednak, Ikeda i wsp. zaznaczają, iż częstość występowania nie różni się między pacjentami z LVNC, a pacjentami z izolowaną dysfunkcją lewej komory. Dlatego też, leczenie opiera się na tej samej zasadzie. Wskazane są tutaj doustne antykoagulanty, szczególnie jeśli mowa o pacjentach z migotaniem przedsionków, dysfunkcją skurczową lewej komory oraz z obecnymi w wywiadzie zdarzeniami zakrzepowo-zatorowymi $[4,7]$. Captur i wsp. szczególnie zalecają stosowanie warfaryny lub acenokumarolu w przypadku pacjentów z izolowaną LVNC i historią uprzednich epizodów zakrzepowych [10]. Oechslin i wsp. również zalecają stosowanie antykoagulantów, aczkolwiek dopiero gdy frakcja wyrzutowa spada poniżej $40 \%$. Niemniej jednak, nie mają oni żadnych badań na poparcie takiego podejścia [9].

Niestety, dotychczas brak jest badań dowodzących, czy stosowanie kwasu acetylosalicylowego przynosi jakiekolwiek korzyści [14].

\section{Niewydolność serca}

Aktualnie przy kardiomiopatii z niescalenia stosowane są wytyczne leczenia standardowej niewydolności serca. Niestety, do tej pory nie ma badań wykazujących korzyść z używania beta-blokerów, blokerów układu renina-angiotensyna-aldosteron, stymulacji dwukomorowej i innych sposobów terapii wykorzystywanych u pacjentów z LVNC. Carrilho-Ferreira i wsp. zaznaczają, iż śmiertelność śródroczna u pacjentów z LVNC jest taka sama jak u pacjentów z kardiomiopatią rozstrzeniową [8].

Ikeda i wsp. podkreślają, iż pacjenci z objawową niewydolnością serca, stopniem III lub IV w skali NYHA, frakcją wyrzutową < 35\% oraz długością zespołu QRS > 120 ms, którzy otrzymują optymalne leczenie farmakologiczne, powinni również otrzymać terapię resynchronizującą serca ze wszczepieniem kardiowertera-defibrylatora, a jeśli niewydolność serca jest oporna na leczenie i terapię przy użyciu ICD, powinien zostać rozważony przeszczep serca [7].

\section{Arytmie}

Szczególnie ważne w przypadku arytmii są arytmie komorowe, jako że mogą one doprowadzić do nagłego zgonu sercowego. Ikeda i wsp. donoszą, iż tachykardie komorowe obecne były u $27 \%$ pacjentów, u których wykonane było monitorowanie holterowskie [7].

W zależności od przypadku możliwe jest stosowanie beta-blokerów, blokerów kanałów wapniowych, amiodaronu albo innych leków antyarytmicznych. Captur i wsp. szczególnie zaznaczają, że opis przypadku 4-miesięcznego noworodka pokazuje, iż leczenie karwedilolem przynosi korzyści względem funkcji i masy lewej komory, a także poprawia wyniki badania scyntygraficznego [10]. Niemniej jednak, takie badania nie zostały przeprowadzone na szeroką skalę [8]. 


\section{Wszczepienie kardiowertera-defibrylatora}

Wszczepienie kardiowertera-defibrylatora jest metodą bardzo kontrowersyjną i choć autorzy badań i prac zaznaczają, iż wszczepienie ICD powinno zostać przeprowadzone u pacjentów z LVNC, którzy zgłaszają omdlenia, objawowe arytmie komorowe, a ich frakcja wyrzutowa spada do 35\%, to jest to metoda wykorzystywana głównie w profilaktyce wtórnej [7-9].

Generalnie, wszczepienie ICD odbywa się u pacjentów z utrwaloną niewydolnością serca, tachykardiami nadkomorowymi, u pacjentów, którzy przeżyli nagłe zatrzymanie krążenia $[10,20]$.

U pacjentów z oporną niewydolnością serca, szczególnie jeśli współwystępuje tachykardia komorowa może być wymagane wszczepienie stymulatora dwukomorowego [14].

Finsterer i wsp. wspominają też o badaniu, w którym u 30 pacjentów z LVNC wszczepiono ICD, z czego 11 w profilaktyce pierwotnej. W efekcie dwóch pacjentów otrzymało nieadekwatną kardiowersję-defibrylację, a tylko u jednego pacjenta tachykardia komorowa została przerwana [14].

\section{Przeszczep serca}

Przeszczepienie serca jest metodą leczenia dla pacjentów w schyłkowej niewydolności serca oraz dla pacjentów opornych na leczenie farmakologiczne [4]. Niemniej jednak, do tej pory w przypadku kardiomiopatii z niescalenia nie była to metoda stosowana na szeroką skalę [8]. Kwalifikacja pacjentów do transplantacji opiera się właśnie na stopniu zaawansowania niewydolności serca i w tym celu wykonuje się szereg badań internistycznych - między innymi ergospirometrię, test 6-minutowego chodu, stężenie markerów, a także mierzy się ciśnienie w tętnicy płucnej oraz ocenia się rzut serca i naczyniowy opór płucny [21, 22].

\section{Wnioski}

Kardiomiopatia z niescalenia jest chorobą ciężką nie tylko w kwestiach leczniczych, ale również w kwestiach diagnostycznych. W zależności od pacjenta, LVNC może być całkowicie bezobjawowa, a w niektórych przypadkach może zostać rozpoznana przy schyłkowej niewydolności serca lub nawet po śmierci pacjenta. Aktualne metody diagnostyczne, kiedy są stosowane pojedynczo, mogą nie być wystarczające do postawienia rozpoznania. W przypadku leczenia, pozostaje nam tylko leczenie objawów kardiomiopatii, wszczepienie kardiowertera-defibrylatora a w końcowym stadium niewydolności serca, przeszczepienie serca. Dużym utrudnieniem w rozwoju diagnostyki i sposobów leczenia jest rzadkość tej choroby, a aktualnie ukazujące się badania pochodzą z reguły z jednego ośrodka i są przeprowadzone na małej ilości pacjentów.

\section{Abstract}

Non-compaction cardiomyopathy is a rare genetic condition and may occur either in a familial form or in a sporadic form. It is characterized by excessive trabeculation and occurrence of deep intertrabecular recesses. Usually the diagnosis is made during an accidental echocardiography or during the screening process of the family members. Although there is no gold standard for the diagnosis, Jenni et al. criteria used during echocardiography examination are the most common. Treatment is based on suppressing the progression of heart failure, thromboembolism prevention and dealing with arrhythmias. Moreover, patients have often cardioverter-defibrillator implanted and they are enrolled on the heart transplant list.

Key words: non-compaction cardiomyopathy, heart failure, echocardiography, magnetic resonance

Folia Cardiologica 2018; 13, 4: 378-385

\section{Piśmiennictwo}

1. Jacquier A, Thuny F, Jop B, et al. Measurement of trabeculated left ventricular mass using cardiac magnetic resonance imaging in the diagnosis of left ventricular non-compaction. Eur Heart J. 2010; 31(9): 1098-1104, doi: 10.1093/eurheartj/ehp595, indexed in Pubmed: 20089517.

2. Mavrogeni S, Sfendouraki E, Theodorakis G, et al. Diagnosis, severity grading and prognosis of left ventricular non-compaction using cardiovascular magnetic resonance. Int J Cardiol. 2013; 167(2): 598-599, doi: 10.1016/j.ijcard.2012.09.234, indexed in Pubmed: 23084112.
3. Rooms I, Dujardin K, De Sutter J. Non-compaction cardiomyopathy: a genetically and clinically heterogeneous disorder. Acta Cardiol. 2015; 70(6): 625-631, doi: 10.2143/AC.70.6.3120173, indexed in Pubmed: 26717209.

4. Towbin JA, Lorts A, Jefferies JL. Left ventricular non-compaction cardiomyopathy. Lancet. 2015; 386(9995): 813-825, doi: 10.1016/ S0140-6736(14)61282-4, indexed in Pubmed: 25865865.

5. Petersen SE, Selvanayagam JB, Wiesmann F, et al. Left ventricular non-compaction: insights from cardiovascular magnetic resonance 
imaging. J Am Coll Cardiol. 2005; 46(1): 101-105, doi: 10.1016/j. jacc.2005.03.045, indexed in Pubmed: 15992642.

6. Niszczota CS, Koleśnik A. Rozwój i morfologia kliniczna prawidłowego serca płodu i dziecka. Sekwencyjna analiza segmentalna serca z wadą wrodzoną. Pediatria Polska. 2012; 87(1): 78-90, doi: 10.1016/ /s0031-3939(12)70598-x.

7. Ikeda U, Minamisawa M, Koyama J. Isolated left ventricular non-compaction cardiomyopathy in adults. J Cardiol. 2015; 65(2): 91-97, doi: 10.1016/j.jjcc.2014.10.005, indexed in Pubmed: 25468766.

8. Carrilho-Ferreira P, Almeida AG, Pinto FJ. Non-compaction cardiomyopathy: prevalence, prognosis, pathoetiology, genetics, and risk of cardioembolism. Curr Heart Fail Rep. 2014; 11(4): 393-403, doi: 10.1007/s11897-014-0227-3, indexed in Pubmed: 25239435.

9. Oechslin E, Jenni R. Left ventricular non-compaction revisited: a distinct phenotype with genetic heterogeneity? Eur Heart J. 2011; 32(12): 1446-1456, doi: 10.1093/eurheartj/ehq508, indexed in Pubmed: 21285074.

10. Captur G, Nihoyannopoulos P. Left ventricular non-compaction: genetic heterogeneity, diagnosis and clinical course. Int J Cardiol. 2010; 140(2): 145-153, doi: 10.1016/j.ijcard.2009.07.003, indexed in Pubmed: 19664830.

11. Zhang W, Chen H, Qu X, et al. Molecular mechanism of ventricular trabeculation/compaction and the pathogenesis of the left ventricular noncompaction cardiomyopathy (LVNC). Am J Med Genet C Semin Med Genet. 2013; 163C(3): 144-156, doi: 10.1002/ajmg.c.31369, indexed in Pubmed: 23843320.

12. De Smet K, Verdries $D$, Tanaka $K$, et al. MRI in the assessment of non ischemic myocardial diseases. Eur J Radiol. 2012; 81(7): 1546-1548, doi: 10.1016/j.ejrad.2011.02.012, indexed in Pubmed: 21392911.

13. Hussein $A$, Karimianpour $A$, Collier $P$, et al. Isolated Noncompaction of the Left Ventricle in Adults. J Am Coll Cardiol. 2015; 66(5): 578-585, doi: 10.1016/j.jacc.2015.06.017, indexed in Pubmed: 26227197.
14. Finsterer J, Stöllberger C, Stöllberger C, et al. Neuromuscular implications in left ventricular hypertrabeculation/noncompaction. Int J Cardiol. 2006; 110(3): 288-300, doi: 10.1016/j.jijcard.2005.10.028, indexed in Pubmed: 16364474.

15. Jenni R, Oechslin E, Schneider J, et al. Echocardiographic and pathoanatomical characteristics of isolated left ventricular non-compaction: a step towards classification as a distinct cardiomyopathy. Heart. 2001; 86(6): 666-671, indexed in Pubmed: 11711464.

16. Arbustini E, Favalli V, Narula N, et al. Left Ventricular Noncompaction: A Distinct Genetic Cardiomyopathy? J Am Coll Cardiol. 2016; 68(9): 949-966, doi: 10.1016/j.jacc.2016.05.096, indexed in Pubmed: 27561770.

17. Chin TK, Perloff JK, Williams RG, et al. Isolated noncompaction of left ventricular myocardium. A study of eight cases. Circulation. 1990; 82(2): 507-513, indexed in Pubmed: 2372897.

18. Grothoff M, Pachowsky M, Hoffmann J, et al. Value of cardiovascular MR in diagnosing left ventricular non-compaction cardiomyopathy and in discriminating between other cardiomyopathies. Eur Radiol. 2012; 22(12): 2699-2709, doi: 10.1007/s00330-012-2554-7, indexed in Pubmed: 22772366.

19. Gati S, Rajani R, Carr-White GS, et al. Adult left ventricular noncompaction: reappraisal of current diagnostic imaging modalities. JACC Cardiovasc Imaging. 2014; 7(12): 1266-1275, doi: 10.1016/j. jcmg.2014.09.005, indexed in Pubmed: 25496545.

20. Thavendiranathan P, Dahiya A, Phelan D, et al. Isolated left ventricular non-compaction controversies in diagnostic criteria, adverse outcomes and management. Heart. 2013; 99(10): 681-689, doi: 10.1136/ /heartjnl-2012-302816, indexed in Pubmed: 23184013.

21. Cierpka L, Durlik M. Transplantologia kliniczna. Przeszczepy narządowe. Wyd. Termedia, Poznań 2015.

22. Barium, Indications and Contraindications. Springer Reference, doi: 10.1007/springerreference_135305. 